\title{
Exploring factors affecting entrepreneurial desirability among Vietnam students
}

\author{
Le Thi Loan ${ }^{a^{*}}$, Vu Quang ${ }^{b}$, Dinh Manh Tuan ${ }^{c}$, Vu Trong Nghia ${ }^{d}$ and Duong Cong Doanh ${ }^{d}$
}

${ }^{a} P h D$ candidate, National Economics University, Vietnam

${ }^{b}$ Hanoi Pedagogical University 2, Vietnam

${ }^{c}$ Institute for European Studies, Vietnam Academy of Social Sciences, Vietnam

${ }^{d}$ National Economics University, Vietnam

\section{H R O N I C L E}

Article history:

Received: January 18, 2020

Received in revised format: February 29, 2020

Accepted: February 29, 2020

Available online: February 29,

2020

Keywords:

The intention of starting a busi-

ness

Lifestyle

Entrepreneurial aptitudes

\section{Introduction}

There is a growing awareness of the concepts of entrepreneurship and entrepreneurs in contemporary society. Entrepreneurship activity not only acts as a catalyst for national economic development but it also creates the number of new jobs for society. Therefore, the need of determination of factors that are associated with entrepreneurial desirability of students is necessary in order to foster youths starting their own business and creating new venture activities. Moreover, this determination is also essential to authorities and government in terms of promulgating suitable law and policy to create effective entrepreneurial ecosystem. Entrepreneurship that is becoming a worldwide phenomenon contributed to economic development across the world (Trang \& Doanh, 2019). Guerrero et al. (2008) state that business venture is seen as an innovative and creative process, which plays the potential role in producing new value to products/services, improving the productivity, bringing new job opportunities, diversifying markets, enhancing social welfare, and promoting the national economy. Historically, the creation of new market, the link with profit orientation and capital investment (Schumpeter, 1975) led to the beliefs of economics regarding to the responsibility of business venture for economic growth (Cole, 1965). Thus, entrepreneurs * Corresponding author.

E-mail address: 1eloan.neu@gmail.com (L. Thi Loan)

(C) 2020 by the authors; licensee Growing Science, Canada. doi: $10.5267 /$ j.ijdns.2020.3.001 
play an important role in developing the national economy, well-being of a society (Iakovleva et al., 2011), innovation and employment (Kelley et al., 2011). The reasons to explain why students do or do not desire to run their own business have been interested by many researchers in entrepreneurship literature (Iakowleva et al., 2011; Krueger et al., 2000; Kolvereid, 1996). Bird and Jellinek (1988) described entrepreneurial desirability as the level of cognitive awareness related to set up a new business. Cognitive issues reflect individual's knowledge and skills involved in performing and operating a new venture. A person' perception of his or her capabilities of carrying out a specific action is a necessary component of motivation and desirability of creating a new business can be involved in the construction of self-efficacy (Doanh \& Bernat, 2019; Krueger, \& Brazeal, 1994).

Even though there are lots of studies related to entrepreneurship field, most of these studies were conducted in developed countries, especially in western societies, where entrepreneurial ecosystem is very developed and business environment is to create the most favorable conditions for entrepreneur. A few researches about entrepreneurial desirability conducted in Vietnam, a transitional economy and a developing country. As a result, there are a number of research gaps in this field that need to fulfill, and authors would like to give additional understanding of student's desirability to become entrepreneur. Also, our study might provide important sightseeing for policy makers, educational reforming in entrepreneurial training and fostering youths starting their own business.

\section{Theory and hypothesis}

\subsection{Entrepreneurship}

Entrepreneurship is the process of creating new venture and new business organization (Shane \& Venkataraman, 2000), that not only provides goods and services, creates job opportunities but also contributes to the development of economy and the national income. While Linda et al. (2017) argued that "it is the process of designing, launching and running a new business", and it also tends to some topics such as policy, government programs, entrepreneurial training, funds, etc. that not only promote the development of starting a new business but it also supports entrepreneurs in their business activities. Therefore, there are many definitions of entrepreneurship. But in general, entrepreneurship is a new business creation by a person alone or cooperating with others.

\subsection{Entrepreneurial desirability}

Entrepreneurial desirability reflects personal perception of creating own business, that included individual' dream, goal and source of satisfaction. Entrepreneurial desirability also reflects the desirability and dream of proving the own value, becoming a leader, the pursuit of self-reliance and greater possibility of self-realization and job satisfaction.

\subsection{Lifestyle}

Nowadays, lifestyle can have a significant influence on the social success, it also brings an individual many opportunities to practice and develop his or her essential skills and capacities in order to become more successful in business activities. Lifestyle entrepreneurship is considered the establishment of an own business that involve in the kind of lifestyle an individual desired. By creating their own business, many entrepreneurs could support their life and their family, they are also free to follow their hobby and desirability. There are many reasons to explain why individual would become a lifestyle entrepreneur, for example, they could be living near their old parents to take care them, or they also can stay at home to raise and educate their young children better, or simply they can be far away from the control of a boss and they can do whatever they want (Linda et al., 2017). Lifestyle also reflects the opportunity bringing to entrepreneurs when they create own business. For instance, independent flexible working hours, selfresponsibility, building higher prestige by themselves, and ability to improve their own qualifications.

$\mathrm{H}_{1}$. Lifestyle is related to the desirability of starting a business in Vietnam. 


\subsection{The need of getting higher income}

Vietnam is still seen as a developing country. Thus, with the low level of the income distribution, there are a number of people creating small business to get survival income. Indeed, some researches proved the strong negative relationship between high benefits of employees, workers, and staffs with the rate of entrepreneurship (Robson, 2007). It means that a country, which has low levels of income, can display a high rate of starting a business. In developing country and transitional economy likewise the case of Vietnam, the shortage of productive labors and the restricted benefits of employment can result in a rise of create a new venture. People are forced to run own small business to earn income to support their families. In developed country, the real flow of income is high and stable, people could hesitate to take risks that is driven from business. The need of getting higher income might play a significant role in making a decision of starting an own business. In Vietnam, for example, many people decide to run a business after the long period of working for a company with a stable salary level and they hope that they can earn greater income from their own business. In addition, a market-oriented economy helped Vietnam transform from one of the poorest countries in the world into a lower middle-income country. Hence, there was a gradual increase in average income level of each citizen. As a result of the explosion of economic development and a number of effective policies, there are many great opportunities for people to become entrepreneurs and gain higher income.

$\mathrm{H}_{2}$. The need of getting higher income is related to the desirability of starting a business in Vietnam.

\subsection{Entrepreneurial aptitude}

Entrepreneurial aptitude is considered the capability, ability and inborn resourcefulness (innate). In addition, entrepreneurial aptitude also refers to the experiences gained from previous jobs and the real, the ability of setting goals and strategies in business, managerial skills and the ability of obeying the law rules and regulations in order to maintain a business profitably. In Vietnam, there are many traditional jobs such as carpentry, dyeing, handicraft and foundry. Many people who were born in these families can obtain the essential experiences and skills in order to start their own business. They also learned business skills from their parents and easily to cope with the change of policy and business environment as well. This can help them maintain the profit of business sustainably.

$\mathrm{H}_{3}$. Entrepreneurial aptitude is related to the desirability of starting a business in Vietnam.

\section{Overview of entrepreneurship situation in Vietnam}

Since the Renovation Process in 1986, Vietnam has transformed from a planned to market-oriented economy. By building the new policies, the Government of Vietnam encouraged internal restructuring. According to the Doing Business 2017 Report of the World Bank, Vietnam ranks $60^{\text {th }}$ among 138 nations in the Global Competitive Report 2017. Vietnam also attracted more FDI than China in 2016 and surpassed Malaysia and Thailand in the Green-field FDI Performance Index, leading in the region (Doanh \& Gadomska-Lila, 2020). Although Vietnam achieves many goals in the development of economy, according to GEM Vietnam report, the entrepreneurship ecosystem almost remains unchanged in comparison with previous years. Fig.1 illustrates the level of the indicators (score from 1 to 5) of conditions of entrepreneurship in Vietnam in two years (2015 and 2013). Overall, in 2015, physical infrastructure continues to be evaluated the highest score in the entrepreneurial ecosystem in Vietnam, reaching 4.07 points, followed by internal market (3.59 points) and Cultural \& Social Norms (3.23 points). However, only 03 out of 12 indicators can reach the average rate ( 3 points) while the last indicators are lower than the average rate. Two indicators have been developed by GEM study in order to evaluate the situation of entrepreneurship development of countries. Firstly, TEA indicator (Total Early-stage Entrepreneurial Activity) refers to new entrepreneurial activities (less than 3.5 years) and just started up business (less than 3 months), Secondly, EB indicator (Established business ownership) refers to persistent entrepreneurial activities (more than 3.5 years). This study indicates that the percentage entrepreneurial intention is rather high, achieving $22.3 \%$, while the TEA rate is only $13.7 \%$ (1\% for business Start-up less than 3 
months and $12.7 \%$ for owner of new entrepreneurial activity less than 3.5 years). It means that in 2015 , nearly 14 of every 100 adults run an own business. In addition, 19.6\% owner/managers established their own business more than 3.5 years.

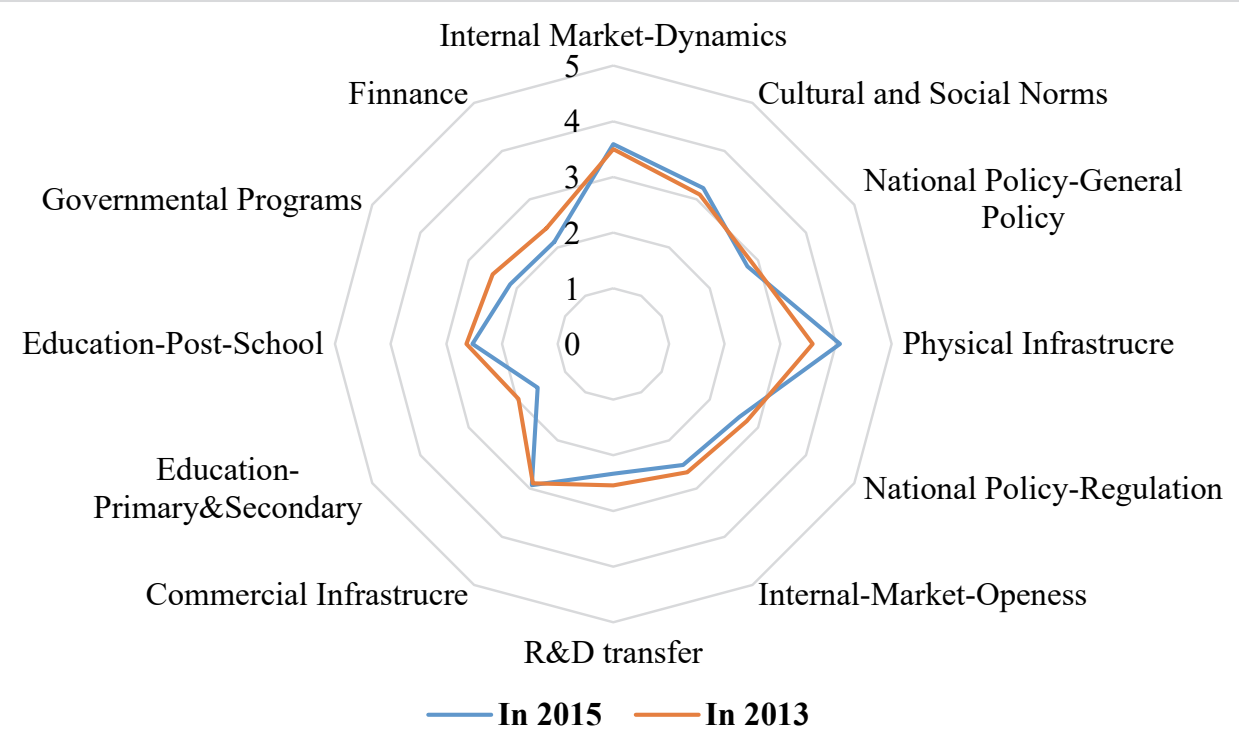

Fig.1. Conditions for entrepreneurship in Vietnam

Source: GEM Vietnam Report 2015/16

In 2015, GEM study also stated that Vietnam stands the $20^{\text {th }}$ out of 60 countries for the rate of entrepreneurial motivations for total early-stage entrepreneurial activity. In ASEAN region, this rate was lower than Indonesia $\left(13^{\text {th }}\right)$ and Philippine $\left(16^{\text {th }}\right)$, while Vietnam only sands higher than Malaysia, and the same with Thailand. Fig. 4 shows the group of young people from 25 to 34 years old had the highest rate of business start-up, followed by the age group from 35-44 years old and 18-24 years old, reaching at 16\% and $13 \%$ respectively. In contrast, this rate among middle and aged people (from 45 to 54 and from 55 64 years old) was very low, only $8 \%$.

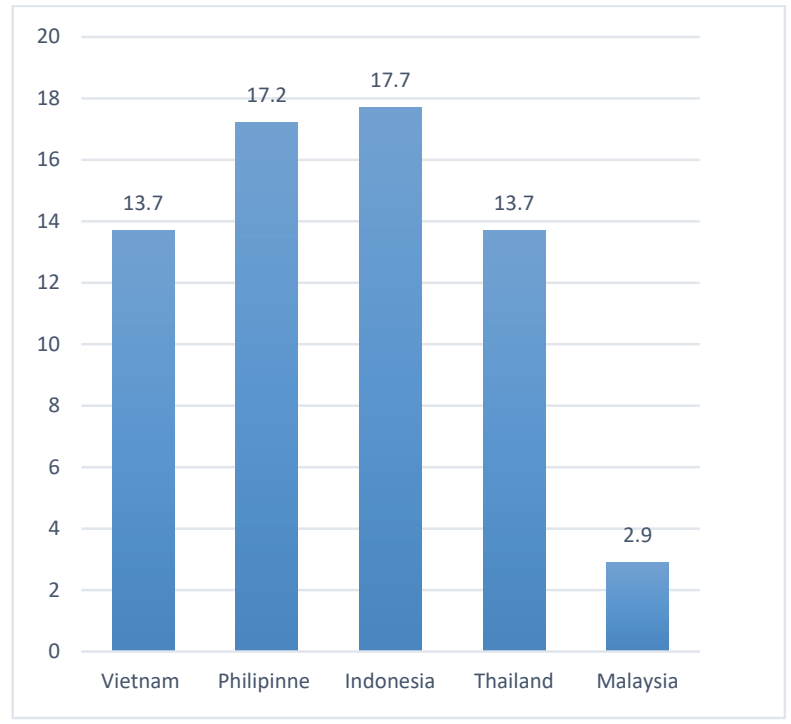

Fig.2. Entrepreneurial development of some countries in ASEAN region in 2015 (unit: \%)

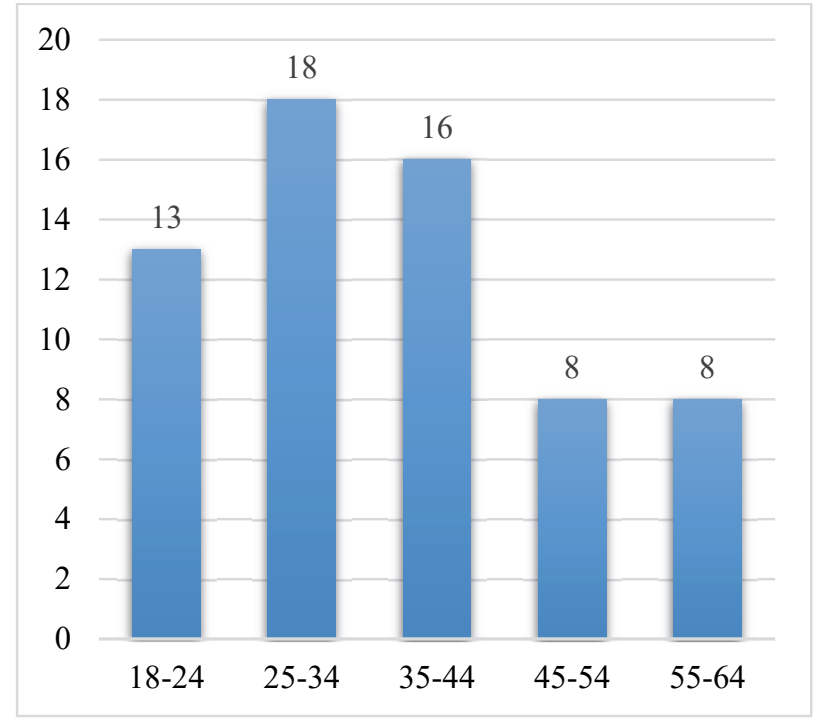

Fig.3. Entrepreneurial development by age group in 2015 (unit: \%) 
In terms of entrepreneurial motivations in Vietnam, only $37.4 \%$ of people who start a business because of no better jobs option (necessity-driven entrepreneurs), while of approximately $62.6 \%$ of those who recognize business opportunity and run their own business (opportunity-driven entrepreneurs).

4. Methods

\subsection{Sample and data collection}

This research mainly focused on the desirability of starting a business. Quantitative method and convenient sampling are used in terms of research techniques. The questionnaire surveys were delivered to 663 students in various schools, colleges, universities and institutions in Vietnam, but almost all these schools, colleges, universities and institutions are placed in the North of Vietnam. Even though 663 students answered the surveys in our SEAMIS project, but only 289 students intended to become entrepreneurs and they answered one section that use for students who desire to starting a business only, while 374 other students either only would like to work for a company or no work/ no self-employment. Our research was designed to assess the academic entrepreneurship in various countries in the context of migration decision and its basic scientific goal is to evaluate the entrepreneurship intentions of students and migration attitudes. However, in the scope of this study, we only focus on entrepreneurial desirability of students and use the data from 289 students who desire to become entrepreneurs. Based on the basic of theory and hypothesis part, the questionnaire was divided into three sections. In the first section, demographic questions are designed to obtain the better information of profile of respondents, which includes ages, genders, education, school year, field of study, current professional activities, and the level of own willingness to take the risks. In the second section, the additional questions are designed to know the information of the type of business activities which students desire to operate, the assessment of students of involving high risks when running own business, the understanding of students of competitors, market, target customers, financial resources, expected income, and activities involved CSR in business plans. Then, in final section, the questions are used to assess the viewpoints of respondents on desirability of starting a business and factors related to this desirability that based on six-point Likert scale ranging 1 (strongly disagree) to 6 (strongly agree).

\subsection{Hypothesized model}

From literature review part, our hypothesized model is proposed:

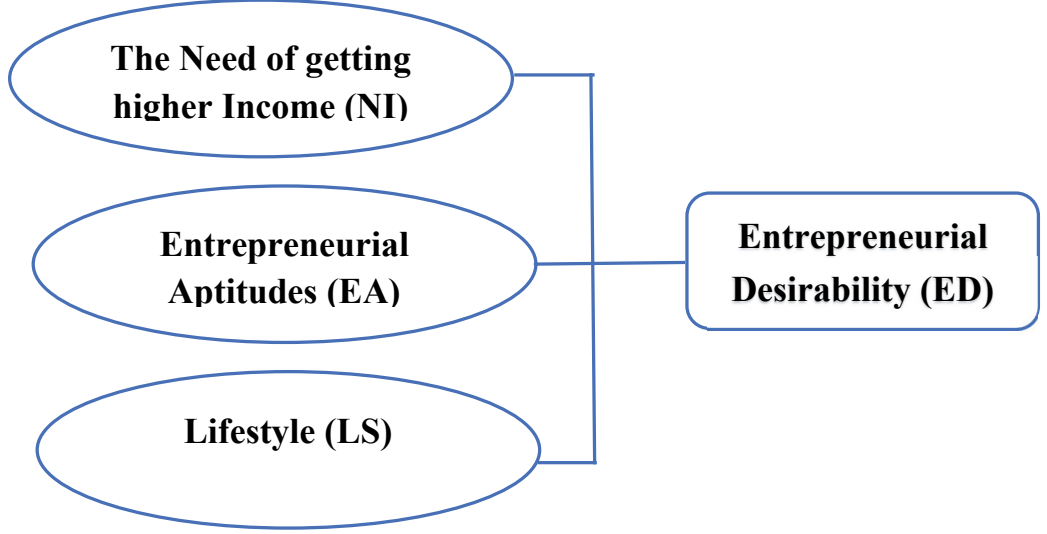

Fig. 1. Research framework

The research framework also could be transformed into the following equation:

$$
\mathrm{yi}_{\mathrm{i}}=\beta_{0}+\beta_{1} \mathrm{X}_{1}+\beta_{2} \mathrm{X}_{2}+\beta_{3} \mathrm{X}_{3}+\varepsilon,
$$

where $y_{i}$ refers to entrepreneurial desirability (ED), $X_{\mathrm{i}}$ refers to independent variables including entrepreneurial aptitudes (EA), the need of getting higher income (NI) and lifestyle (LS). 


\subsection{Factor analysis and reliability}

The statistics software SPSS 20.0 is used to perform explorative factor analysis (EFA) by using three indicators such as KMO measure (Kaiser-Meyer-Olkin), Bartlett's test of sphericity and Eigenvalue for three independent variables and one dependent variable composing of 16 attributes. Moreover, some tools of descriptive statistics were also used to indicate the demographic information of the samples. In addition, multiple regressions were used to identify the relationship between dependent and independent variables.

\section{Table 1}

Summary of variables

\begin{tabular}{|c|c|c|}
\hline Variables & Number of items & Cronbach's Alpha \\
\hline 1. Entrepreneurial Desirability (ED) & 4 & 0.718 \\
\hline 2. Lifestyle (LS) & 4 & 0.929 \\
\hline 3. Entrepreneurial Aptitudes (EA) & 4 & 0.756 \\
\hline 4. The Need of getting higher income (NI) & 4 & 0.771 \\
\hline
\end{tabular}

According to the results from Table 1, Cronbach's coefficients alpha of all variables ranges from 0.718 to 0.929 . Thus, the internal consistency of these variables is secure.

Table 2

KMO and Bartlett's Test

\begin{tabular}{llll}
\hline \multicolumn{2}{l}{ Type of variables } & Independent & Dependent \\
\hline \multicolumn{2}{l}{ Kaiser-Meyer-Olkin Measure of Sampling Adequacy. } & 0.907 & 0.677 \\
& Approx. Chi-Square & 2306.346 & 239.903 \\
\multirow{2}{*}{ Bartlett's Test of Sphericity } & df & 66 & 6 \\
& Sig. & 0.000 & 0.000 \\
\hline
\end{tabular}

The results of EFA shows that KMO reaches 0.917 and 0.677 for the group of independent variables and dependent variable respectively. Technically, with 289 students, the factor loadings of EFA should be higher than 4.0. The value of KMO must range from 0.5 to 1.0 in order to be acceptable. Hence, the value of KMO at 0.917 and 0.677 are seen as the acceptable value. The Bartlett's test of sphericity significant level must be lower than 0.05 (Pallant J., 2005). In addition, the value of eigenvalue of independent variables and dependent variable are 1.470 and 2.188 that is higher than 1. Moreover, as a result of EFA for independent variables, the extraction sum of squared loadings is 66.092 which represented for $66.1 \%$ of total variance.

5. Result

\subsection{Demographic profile}

Table 3

Descriptive Statistics of Sample Demographics

\begin{tabular}{lllll}
\hline \multicolumn{2}{c}{ Demographic variables } & & Frequency & Percentage (\%) \\
\hline 1. & Age & $18-19$ years old & 49 & 17 \\
& & $20-24$ years old & 237 & 82 \\
& & Over 24 years old & 3 & 1 \\
\hline 2. & Gender & Male & 115 & 39.8 \\
& & Female & 174 & 60.2 \\
\hline 3. & Field of study & Economic & 218 & 75.4 \\
& & Non-economic & 71 & 24.6 \\
\hline 4. & Education & High School & 31 & 4.7 \\
& & University/College & 254 & 87.9 \\
\cline { 3 - 5 } 5. & Current job & Onster & 4 & 1.4 \\
& & Studying and working for a company & 90 & 31.1 \\
& & Studying and running own business & 115 & 39.8 \\
& & Studying and looking for a job & 22 & 7.6 \\
& & & 62 & 21.5 \\
\hline
\end{tabular}


Most respondents belong to the age group from 20 to 24 years old, therefore, almost all of them are the third year or final year students. Interestingly, $60.2 \%$ of respondents are female, but there are only $24.6 \%$ non-economic students. The proportion of university and college students is very high, reaching at $87.9 \%$, while high school students and master students account for $4.7 \%$ and $1.4 \%$ respectively. In terms of current professional (working) activities, 39.8\% respondents are both studying and working for a company, $31.1 \%$ of them only focus on studying, whereas only $7.6 \%$ respondents is both studying and running their own business.

\subsection{Descriptive statistics for supplement questions}

In second section of our survey, supplement questions are used to assess the willingness level of involving high risks, business field students desired to participate, business plans involved CSR activities and the awareness of students of competitors, target customer groups, and necessity of skills and qualification obtained from university.

\section{Table 4}

Descriptive statistics for supplement questions

\begin{tabular}{|c|c|c|c|c|}
\hline & Mean & Median & Mode & Std. Deviation \\
\hline 1. Willingness to take the risks & 3.332 & 3 & 3 & 0.905 \\
\hline 2. Business field desired to operate & 2.635 & 3 & 4 & 1.339 \\
\hline 3. Starting up own business involved to high risks & 1.319 & 1 & 1 & 0.562 \\
\hline 4. Understanding how to set up an own business & 1.434 & 1 & 1 & 0.496 \\
\hline 5. Being aware of competitors in the market & 1.298 & 1 & 1 & 0.458 \\
\hline 6. Knowing target customers & 1.224 & 1 & 1 & 0.417 \\
\hline 7. Having assets and financial resources & 1.855 & 2 & 2 & 0.356 \\
\hline 8. Taking account into CSR activities in business plans & 1.318 & 1 & 1 & 0.425 \\
\hline 9. Understanding how to organize financial resources effectively & 1.236 & 1 & 1 & 0.500 \\
\hline 10. Necessity of skills and qualification obtained from university & 2.616 & 2 & 1 & 1.566 \\
\hline
\end{tabular}

Note: $\mathrm{N}=289$

Table 4 indicates descriptive statistics such as mean, median, mode and standard deviation for supplement questions. According to the results of our study, when asking students about their willingness to take the risks in business, ranging from 1 (lowest) to 5 (highest), $30.1 \%$ of them be willing to take risk at high level, $43.6 \%$ at middle level, $10.4 \%$ at highest level and only $14.2 \%$ at low level. $36.1 \%$ students answer that business field that they desire to operate is service, and just $5.9 \%$ for production field. Noticeably, $72.9 \%$ respondents said that stating up own business will involve to high risks, while just more than half of them (56.6\%) think that they know how to set up an own business. In terms of being aware of competitors and target customers in the market, $70.1 \%$ respondents agree that they know who is (will be) competing with, and $77.6 \%$ of them know who are (will be) target customers. Whereas only $14.9 \%$ respondents have assets and financial resources need to start up, $85.1 \%$ of them said that they do not have. On behalf of paying attention in CSR (Corporate Social Responsibility) activities, $76.4 \%$ respondent said yes and $23.6 \%$ said no. Unfortunately, nearly a half of students $(47.4 \%)$ do not know how to organize financial resources to start a business. In addition, $34.3 \%$ students think that the knowledge which they study at university and college is useful, while $20.8 \%$ of the students study only because of earning diploma. $13.1 \%$ respondents believe that skills and qualifications obtained from university is not useful, but $19 \%$ of them said that it is difficult to say because they are still studying.

\subsection{Correlation coefficients between variables}

Table 5 compares the correlation relationships between dependent variable (DE) and the independent variables (NI, EA, LS). In Pearson correlation analysis, if the value ranges from 0.50 to 1.0 , it means that the strong correlation. As a result of study, with the significance at $0.01(p<0.01)$, there is a strong positive correlation between NI and ED ( $\mathrm{r}=0.719)$, EA and ED (0.738), LS and ED (0.709). In other words, the correlation analysis shows the strong positive relationship between the need of getting higher income and desirability of starting a business, entrepreneurial aptitudes and entrepreneurial desirability, lifestyle and desirability of creating a business. 
Table 5

Correlation coefficients between variables

\begin{tabular}{llllll}
\hline & & NI & EA & LS & ED \\
\hline NI & Pearson Correlation & 1 & $0.628^{* *}$ & $0.609^{* *}$ & $0.719^{* *}$ \\
& Sig. (2-tailed) & & 0.000 & 0.000 & 0.000 \\
\hline EA & Pearson Correlation & $0.628^{* *}$ & 1 & $0.758^{* *}$ & $0.738^{* *}$ \\
& Sig. (2-tailed) & 0.000 & & 0.000 & 0.000 \\
\hline \multirow{2}{*}{ LS } & Pearson Correlation & $0.609^{* *}$ & $0.0758^{* *}$ & 1 & $0.709^{* *}$ \\
& Sig. (2-tailed) & 0.000 & 0.000 & & 0.000 \\
\hline ED & Pearson Correlation & $0.719^{* *}$ & $0.738^{* *}$ & $0.709^{* *}$ & 1 \\
& Sig. (2-tailed) & 0.000 & 0.000 & 0.000 & \\
\hline
\end{tabular}

Note: $\mathrm{N}=289 ; *: \mathrm{p}<0.05, * *: \mathrm{p}<0.01(2-$ tailed $)$

\subsection{Multiple regression}

Multiple regression analysis is used to predict the value of dependent variable (ED) based on the value of independent variables.

Table 6

Model Summary ${ }^{\mathrm{a}}$

\begin{tabular}{ccccll}
\hline Model & $\mathrm{R}$ & $\begin{array}{l}\mathrm{R} \\
\text { Square }\end{array}$ & Adjusted R Square & $\begin{array}{l}\text { Std. Error of the Esti- } \\
\text { mate }\end{array}$ & $\begin{array}{l}\text { Durbin-Wat- } \\
\text { son }\end{array}$ \\
\hline 1 & $0.825^{\text {a }}$ & 0.681 & 0.678 & 0.53431 & 1.761 \\
\hline a. & $\begin{array}{l}\text { Predictors: (Constant), NI, EA, LS } \\
\text { b. }\end{array}$ & & & \\
\end{tabular}

According to the results in Table 6 , Adjusted $\mathrm{R}^{2}$ value tells us that our model makes up $68.1 \%$ of variance in the spelling scores. Moreover, Durbin-Watson valued at $1.76 \ni(1.5,2.5)$. Thus, it is a very good model.

Table 7

ANOVA $^{\mathrm{a}}$

\begin{tabular}{llllll}
\hline Model & Sum of Squares & df & Mean Square & F & Sig. \\
\hline Regression & 173.048 & 3 & 57.683 & 202.052 & $0.000^{\mathrm{b}}$ \\
Residual & 81.077 & 284 & 0.285 & & \\
\hline
\end{tabular}

a. Dependent Variable: ED

b. Predictors: (Constant), NI, EA, LS

Table 7 shows an ANOVA, which reports the overall significance our model research. As Sig. $<0.05$ $(p<0.05)$, our model is significance. The final result (Table 7) indicates that there are three independent variables (NI, EA, LS) which effects at the high confident level on dependent variable (ED). Specially, $\mathrm{NI}(\beta=0.363, p=0.000)$ has the strongest impact on $\mathrm{ED}$, followed by EA $(\beta=0.353, p=0.000)$ and LS $(\beta=0.220, p=0.000)$.

\section{Table 8}

Coefficients $^{\mathrm{a}}$

\begin{tabular}{|c|c|c|c|c|c|c|c|}
\hline \multirow[t]{2}{*}{ Model } & \multicolumn{2}{|c|}{$\begin{array}{l}\text { Unstandardized } \\
\text { Coefficients }\end{array}$} & \multirow{2}{*}{$\begin{array}{ll}\begin{array}{l}\text { Standardized } \\
\text { Coefficients }\end{array} \\
\text { Beta }\end{array}$} & \multirow[t]{2}{*}{$\mathrm{t}$} & \multirow[t]{2}{*}{ Sig. } & \multicolumn{2}{|c|}{ Collinearity Statistics } \\
\hline & $\mathrm{B}$ & Std. Error & & & & Tolerance & VIF \\
\hline (Constant) & 0.147 & 0.125 & & 1.174 & 0.241 & & \\
\hline NI & 0.363 & 0.045 & 0.363 & 8.135 & 0.000 & 0.564 & 1.772 \\
\hline EA & 0.369 & 0.057 & 0.353 & 6.506 & 0.000 & 0.381 & 2.622 \\
\hline LS & 0.196 & 0.047 & 0.220 & 4.131 & 0.000 & 0.396 & 2.528 \\
\hline
\end{tabular}

a. Dependent Variable: ED 
Based on the results, all hypotheses are accepted and we can conclude as following:

$\mathrm{H}_{1}$. Lifestyle positively is related to the desirability of starting a business in Vietnam

$\mathrm{H}_{2}$. The need of getting higher income positively is related to on the desirability of starting a business in Vietnam

$\mathrm{H}_{3}$. Entrepreneurial aptitude is positively related to on the desirability of starting a business in Vietnam.

Thus, we can complete the equation $(1): \quad \mathrm{ED}=0.147+0.363 \times \mathrm{NI}+0.353 \times \mathrm{EA}+0.220 \times \mathrm{LS}+\varepsilon$

\section{Conclusion}

The purpose of this research was to investigate the effects of the need of getting higher income, entrepreneurial aptitudes and lifestyle on the desirability of starting up a business in Vietnam. During the research, although there were rather many studies on this topic in developed countries, very little researches were founded in Vietnam- a transitional economy. This research might contribute to overall understanding about entrepreneurial field in Vietnam and might provide recommendations for policy makers, universities, colleges, institutions in order to foster entrepreneurship by youths and develop entrepreneurial ecosystem. The study also examines the factors affecting on the desirability of starting an own business. Throughout overview of entrepreneurial situation of Vietnam, authors indicated some viewpoints of economy of Vietnam, entrepreneurial ecosystem, and development of entrepreneurship in Vietnam. Demographic profile was presented to provide some general information of respondents; then some supplement questions was designed to investigate some awareness of students of entrepreneurship. Finally, from the results of factor analysis and linear regression, authors showed the positive correlations between three independent variables (NI, EA, LS) and dependent variable (ED). In other words, the need of getting higher income, entrepreneurial aptitudes and lifestyle has positive influences on the entrepreneurial desirability.

The findings from this research is able to serve as a useful information for further researches. Further research should increase the size of samples and use different variables such as training programs, cultural and social norms, etc. in the research framework in order to investigate other factors related to entrepreneurial intention of youths.

\section{References}

Bird, B., \& Jelinek, M. (1989). The operation of entrepreneurial intentions. Entrepreneurship theory and practice, 13(2), 21-30.

Cole, A.H. (1965). An approach to the study of entrepreneurship, in Aitken, H.G. (ed.), Explorations in enterprise. Harvard University Press, Cambridge, Mass. 30-44.

Doanh, D. C., \& Bernat, T. (2019). Entrepreneurial self-efficacy and intention among Vietnamese students: a meta-analytic path analysis based on the theory of planned behavior. Procedia Computer Science, 159, 2447-2460.

Doanh, D.C., \& Gadomska-Lila, K. (2020). Customers' awareness of corporate social responsibility in Vietnam and Poland: A comparative analysis. Folia Oeconomica, 1(346), 1-20.

Guerrero, M., Rialp, J., \& Urbano, D. (2008). The impact of desirability and feasibility on entrepreneurial intentions: A structural equation model. International Entrepreneurship and Management Journal, 4(1), 35-50.

Iakovleva, T., Kolvereid, L. \& Stephan, U. (2011). Entrepreneurial intentions in developing and developed countries. Education and Training, 53(5), 353-370.

Krueger, N. F., Reilly, M. D., \& Carsrud, A. L. (2000). Competing models of entrepreneurial intentions. Journal of Business Venturing, 15(5), 411-432.

Krueger, N. F., Jr., \& Brazeal, D. V. (1994). Entrepreneurial potential and potential entrepreneurs. Entrepreneurship Theory \& Practice, 18, 91-104. 
Kolvereid, L. (1996). Organizational employment versus self-employment: Reasons for career intentions. Entrepreneurial Theory and Practice, 23(3), 23-31.

Linda, L.L., Ana, V.P., \& Cheng-Nam, C. (2017). Factors related to the intention of starting a new business in EL Salvador. Asia Pacific Management Review, 22, 212-222.

Pallant, J. (2005), SPSS survival Manual: A Step by Step Guide to Data Analysis Using SPSS, 12nd ed., Maidenhead, Berkshire: Open University Press, ch. 15, pp. 172-193.

Robson, M. (2007). Explaining Cross-Country Variations in Entrepreneurship: The Role of Social Protection and Political Culture. Comparative Labor Law and Policy Journal, 28, 863-892

Shane, S. \& Venkataraman. S. (2000). The promise of entrepreneurship as a field of research. Academy of Management Review, 25(1), 217-226.

Schumpeter, J.A. (1975). Capitalism, socialism and democracy. 3rd edition, New York, Harper and Row. Trang, T., \& Doanh, D. (2019). The role of structural support in predicting entrepreneurial intention: Insights from Vietnam. Management Science Letters, 9(11), 1783-1798.

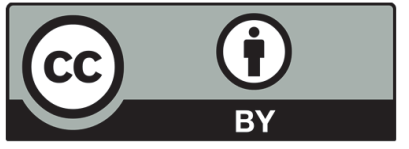

(C) 2020 by the authors; licensee Growing Science, Canada. This is an open access article distributed under the terms and conditions of the Creative Commons Attribution (CC-BY) license (http://creativecommons.org/licenses/by/4.0/). 